\title{
UNUSUAL GIANT CELL LESIONS IN BIOPSY SPECIMENS OF LEFT ATRIAL APPENDAGES IN MITRAL STENOSIS
}

\author{
BY \\ E. M. HUSBAND AND R. LANNIGAN \\ From the Department of Pathology, University of Birmingham, The Medical School, Birmingham 15 \\ Received June 17, 1964
}

Mitral stenosis in the adult is generally accepted as being in most cases the result of rheumatic fever, cases attributable to other causes being few, e.g. amyloidosis (Koletsky and Stecher, 1939) and possibly rheumatoid disease (Bywaters, 1950; Cruickshank, 1958).

Since mitral valvotomy was introduced 465 left atrial biopsies have been examined histologically in the United Birmingham Hospitals. The structural features and the incidence of rheumatic lesions in the first 175 specimens have been described (Lannigan, 1959, 1961). Nodular cellular lesions were present in the endocardium or subendocardium in 58 per cent of specimens and in a fürther 6 per cent there were non-specific changes. These lesions corresponded in structure to those found in a control post-mortem series of rheumatic heart disease.

In 3 biopsy specimens of the left atrial appendages we have noted peculiar cellular lesions that do not resemble those of rheumatic carditis.

\section{Clinical Features}

Clinically these patients were believed to be straightforward cases of rheumatic mitral stenosis and at operation the presence of stenosis was confirmed. The major clinical features are shown in the Table.

TABLE

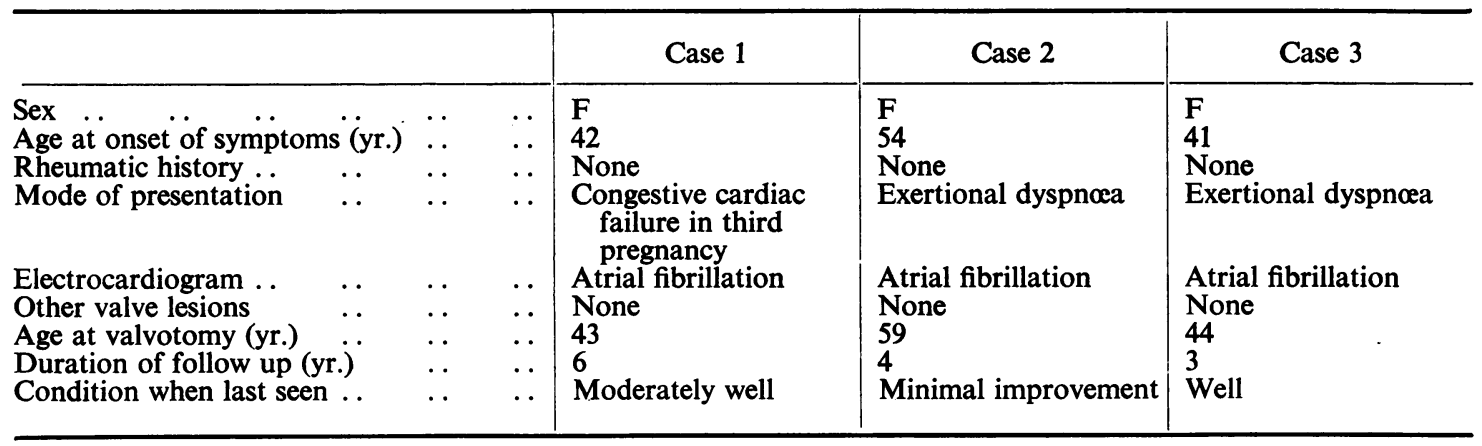

In Case 1 the diagnosis of mitral stenosis was made only during the patient's third pregnancy; in Case 2 it was made a few weeks before valvotomy at the time the patient was first referred to hospital; in Case 3 the diagnosis was made three years before valvotomy. None of the patients had had a previous thoracic operation.

\section{HistologY}

All specimens show similar lesions but they are most extensive in Case 2.

An extensive inflammatory reaction is present in the myocardium (Fig. 1). This sometimes occurs in 


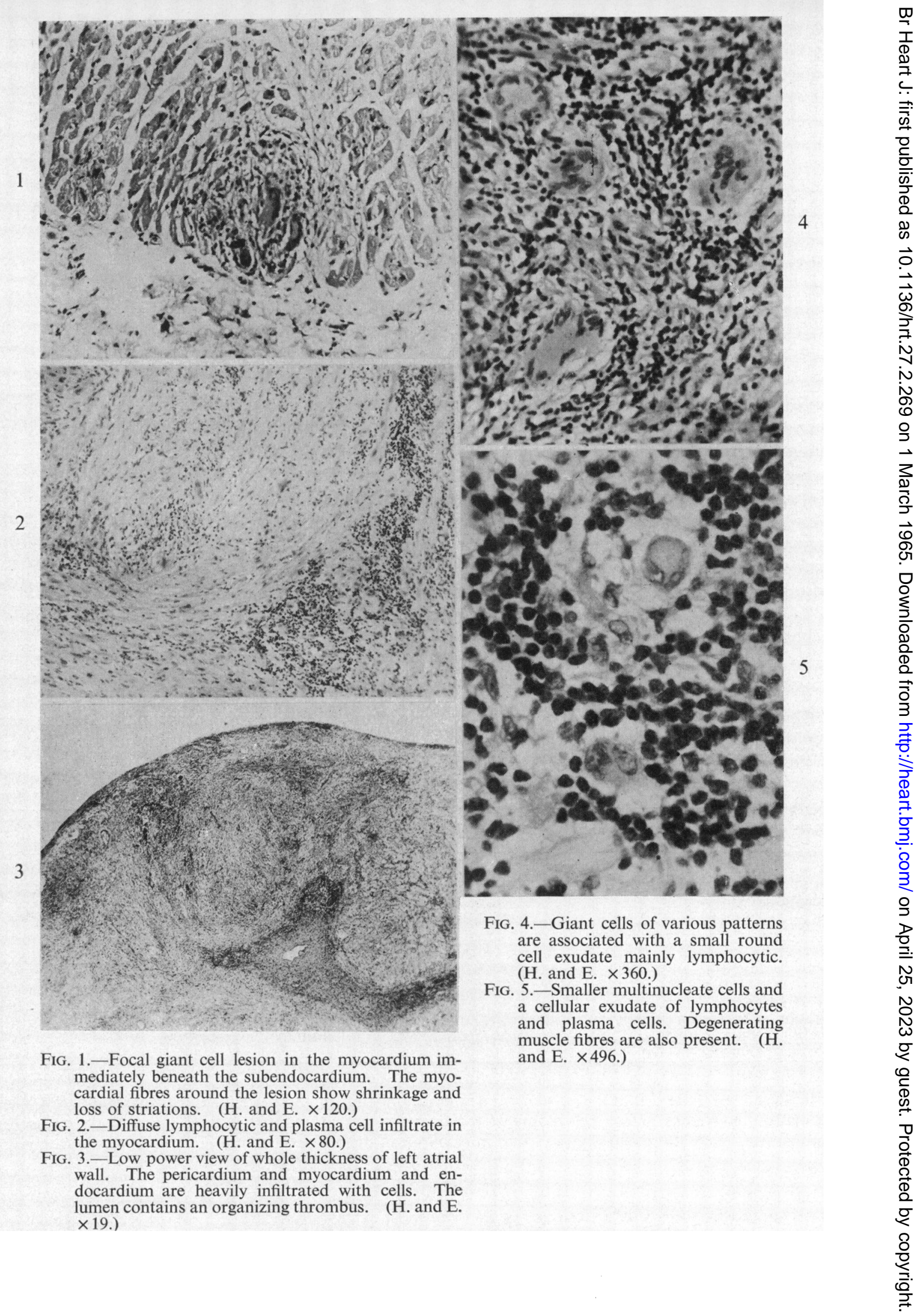


small focal areas (Fig. 2 and 3) but is usually diffuse. The cellular exudate consists mainly of lymphocytes and plasma cells with large numbers of giant cells (Fig. 4). Only a few mononuclears are present and occasional eosinophils are found throughout the affected areas. The myocardium itself and the broad fibrous septa are heavily involved and the giant cells are found closely associated with degenerating muscle (Fig. 1 and 5). The giant cells show considerable variation in size and appearance. In some the nuclei are arranged at the periphery similar to Langhan's cells, others have an equatorial arrangement of nuclei, and in the remainder the nuclei are distributed throughout the cytoplasm. The number of nuclei varies from 2 to 40 in one plane (Fig. 4 and 5).

The cytoplasm is eosinophilic and stains red with the Masson or picro-Mallory stains. Striations have not been demonstrated in the cytoplasm, but on rare occasions a multinucleate mass is continuous with a degenerating muscle fibre in which striations are still present. The giant cells do not contain cytoplasmic inclusions.

Although in some areas small focal lesions are present, these do not have follicular appearance. There is no evidence of tubercle formation, epithelioid cell collections, caseation, or other forms of necrosis. In Case 2 there is extensive fibrosis within and between the cellular lesions.

The myocardial fibres within the inflammatory areas and in the immediate vicinity show shrinkage, vacuolation, loss of striations, and sometimes areas of myocytolysis are present. The pericardium is involved in all three cases, showing a lymphocytic infiltration that is diffuse in Case 2 and focal in Cases 1 and 3. In one area in Case 2 there are small numbers of giant cells immediately adjacent to the myocardium, but none are found in the other two cases. The endocardium in all cases contains organizing thrombus. In Case 2 there are focal collections of lymphocytic and mononuclear cells in the subendocardium not related to the thrombus.

Bacteria including acid-fast bacilli, fungi, or other parasites have not been demonstrated in sections and no foreign body material has been found.

\section{Discussion}

The lesions present in these cases bear no resemblance to those of rheumatic heart disease and Aschoff nodules were not found in the endocardium or subendocardium.

The differential diagnosis appears to lie between tuberculosis, certain fungus infections, sarcoidosis, and diffuse giant cell myocarditis.

The absence of tubercle formation, caseation, and the negative Ziehl-Neelsen stain for acid-fast bacilli exclude the diagnosis of tuberculosis. There was no radiological evidence of pulmonary tuberculosis and there were no other clinical features to support such a diagnosis.

Similar considerations apply to fungus infections, such as histoplasmosis, which occasionally involve the heart and produce granulomatous lesions. None of the patients had lived abroad and fungus infections are extremely rare in this country.

The heart is involved in approximately 20 per cent of cases of sarcoidosis (Longcope and Freiman, 1952). In some this is symptomless but in others there appears to be predilection for the conducting system (Porter, 1960; Phinney, 1961). Though the cardiac lesions are not so well defined as in, for example, lymph nodes, the basic pattern of histiocytic cells, giant cells, and lymphocytic cells can be recognized (Yesner and Silver, 1951). Follicular formation can often be clearly recognized though the follicles may be confluent and form large masses. In a few cases sarcoidosis has been reported in association with valvular disease of the heart, but Aschoff nodules have been present in addition to the sarcoid lesions (Botti and Young, 1959). One case was diagnosed in a left atrial appendage biopsy taken at valvotomy (Thorbjarnarson and Glenn, 1956). However, one is reported in which there was no evidence of rheumatic carditis (Laroche et al., 1955).

Although there is a superficial resemblance to sarcoidosis in these cases, the inflammatory reaction is almost exclusively lymphocytic and plasma cell with a scattering of eosinophils. The giant cells are variable in size and shape and appear to be derived from muscle cells. The pericardium is heavily involved, but giant cells were only found in one case close to the myocardium and these could have been derived from muscle. But it is difficult to be certain of the origin of giant cells in the myocardium (Dilling, 1956).

Clinically there was nothing to suggest sarcoidosis; Kwein tests were not carried out. 
The term giant cell myocarditis has been applied to cover a group of cases with focal granulomatous lesions in which no organisms can be demonstrated and another group in which a diffuse type of reaction is present. Dilling (1956) was able to find 13 recorded cases of giant cell myocarditis in which the Wasserman reaction was negative, and the descriptions are similar to the cases described here. Clinically, however, the present cases do not conform to previously described giant cell myocarditis. In the latter, rapidly progressive cardiac failure resulting in death in a few months or sudden death has been the rule (Corby, 1960). None of the previously reported cases have been associated with mitral valve lesions. It must be remembered, however, that the diagnosis has been established post mortem, and there is no other means of making such a diagnosis. It is likely, in view of the large numbers of diseases that may produce a myocarditis (Gore and Saphir, 1947), that the heart is involved in many episodes of myocarditis from which recovery takes place.

Significance of Lesions in Relation to Mitral Stenosis. The presumption that most cases of mitral stenosis are rheumatic is based on necropsy studies and more recently on biopsy material from valvotomy cases. The only diagnostic feature is the presence of Aschoff bodies, and these are present after death in only a small proportion of cases of mitral disease. Even in biopsy specimens where the incidence of Aschoff nodules has been as high as 75 per cent (Gil, Rodriguez, and Ibarra, 1955) there still remain many where it is impossible to be certain of the diagnosis. In biopsy material, doubt has been cast by some authors on the rheumatic nature of the lesions (Enticknap, 1953; Saphir, 1959), though most others by comparative studies after death have accepted that they are rheumatic (Decker, Hawn, and Robbins, 1953; Thomas et al., 1953).

The lesions described in these three cases may well be coincidental and have no relevance to the mitral valve lesions. However, all cases were in the older age-group, none had a history of rheumatic fever, and the clinical history was short. One patient had gone through two pregnancies without a valve lesion being diagnosed. The possibility that the valve lesions are not rheumatic and are related to the myocarditis cannot be excluded.

\section{SUMMARY}

Three cases of mitral stenosis are described in which left atrial biopsies at valvotomy showed lesions similar to those of giant cell myocarditis. The relationship of the mitral stenosis to the giant cell lesions is discussed.

We wish to thank Dr. Bishop and Professor d'Abreu for the clinical information.

\section{REFERENCES}

Botti, R. E., and Young, F. E. (1959). Myocardial sarcoid, complete heart block and aortic stenosis. Ann. intern. Med., 51, 811.

Bywaters, E. G. L. (1950). The relation between heart and joint disease including "rheumatoid heart disease" and chronic post-rheumatic arthritis (type Jaccoud). Brit. Heart J., 12, 101.

Corby, C. (1960). Isolated myocarditis as a cause of sudden obscure death. Med. Sci. and the Law, 1, 23.

Cruickshank, B. (1958). Heart lesions in rheumatoid disease. J. Path. Bact., 76, 223.

Decker, J. P., Hawn, C. van Z., and Robbins, S. L. (1953). Rheumatic " activity." as judged by the presence of Aschoff bodies in auricular appendages of patients with mitral stenosis. Circulation, 8, 161.

Dilling, N. V. (1956). Giant-cell myocarditis. J. Path. Bact., 71, 295.

Enticknap, J. B. (1953). Biopsy of the left auricle in mitral stenosis. Brit. Heart J., $15,37$.

Gil, J. R., Rodriguez, H., and Ibarra, J. J. (1955). Incidence of asymptomatic, active rheumatic cardiac lesions in patients submitted to mitral commissurotomy and the effect of cortisone on these lesions. Amer. Heart J., $\mathbf{5 0}, 912$.

Gore, I., and Saphir, O. (1947). Myocarditis: A classification of 1402 cases. Amer. Heart J., $34,827$.

Koletsky, S., and Stecher, R. M. (1939). Primary systemic amyloidosis. Arch. Path., 27, 267.

Lannigan, R. (1959). The rheumatic process in the left auricular appendage. J. Path. Bact., 77, 49.

(1961). Sub-clinical rheumatic carditis. Brit. Heart J., 23, 35.

Laroche, C., de Gennes, J. L., Hazard, J., and Samarcq, P. (1955). Maladie de Besnier-Boeck-Schaumann avec manifestations polyarticulaires et localisations endo-péricardiques mortelles. Bull. Soc. méd. Hôp Paris, $71,908$.

Longcope, T., and Freiman, D. G. (1952). A study of sarcoidosis. Medicine (Baltimore), $31,1$.

Phinney, A. O., Jr. (1961). Sarcoid of the myocardial septum with complete heart block. Report of two cases. Amer. Heart J., 62, 271. 
Porter, G. H. (1960). Sarcoid heart disease. New Engl. J. Med., 263, 1350.

Saphir, O. (1959). Editorial - Myocarditis. Amer. Heart J., 57, 639.

Thomas, W. A., Averill, J. H., Castleman, B., and Bland, E. F. (1953). The significance of Aschoff bodies in the left atrial appendage. New Engl. J. Med., 249, 761.

Thorbjarnarson, B., and Glenn, F. (1956). Sarcoidosis associated with sudden death during mitral valvulotomy. Arch. Surg., 73, 862.

Yesner, R., and Silver, M. (1951). Fatal myocardial sarcoidosis. Amer. Heart J., 41, 777.

\section{ADDENDUM}

Since this paper was submitted a similar case has been reported by P. C. McCrea and R. W. Childers ("Two unusual cases of giant cell myocarditis with mitral stenosis and Wegener's syndrome", Brit. Heart J. 1964, 26, 490). 